This item was submitted to Loughborough's Research Repository by the author.

Items in Figshare are protected by copyright, with all rights reserved, unless otherwise indicated.

\title{
Influence of Niobium Pentoxide particulates on the properties of Brushite/Gelatin/Alginate membranes
}

PLEASE CITE THE PUBLISHED VERSION

https://doi.org/10.1016/j.xphs.2018.01.014

\section{PUBLISHER}

Elsevier

VERSION

AM (Accepted Manuscript)

\section{PUBLISHER STATEMENT}

This work is made available according to the conditions of the Creative Commons Attribution-NonCommercialNoDerivatives 4.0 International (CC BY-NC-ND 4.0) licence. Full details of this licence are available at: https://creativecommons.org/licenses/by-nc-nd/4.0/

\section{LICENCE}

CC BY-NC-ND 4.0

\section{REPOSITORY RECORD}

Beherei, Hanan H., Abdallah A. Shaltout, Mostafa Mabrouk, Nayera A.M. Abdelwahed, and Diganta Bhusan Das. 2018. "Influence of Niobium Pentoxide Particulates on the Properties of Brushite/gelatin/alginate Membranes”. figshare. https://hdl.handle.net/2134/36246. 


\title{
Influence of niobium pentoxide particulates on the properties of nano- brushite/gelatin/alginate membranes
}

\author{
Hanan H. Beherei ${ }^{1 *}$, Abdallah A. Shaltout ${ }^{2,3}$, Mostafa Mobrouk ${ }^{1^{*}}$, Nayera A.M. \\ Abdelwahed ${ }^{4}$, Diganta B. Das ${ }^{5 *}$
}

${ }^{1}$ Refractories, Ceramics and Building Materials Department, National Research Centre, 33El Bohouth Street (former EL Tahrir Street.), Dokki, PO Box 12622, Giza, Egypt

${ }^{2}$ Physics Department, Faculty of Science, Taif University, 21974 Taif, P.O. Box 888, Saudi Arabia

${ }^{3}$ Spectroscopy Department, Physics Division, National Research Centre, El Behooth Street, 12622 Dokki, Cairo, Egypt

${ }^{4}$ Chemistry of Natural and Microbial Products Department, Pharmaceutical Industries Division, National Research Centre, 33 EL Bohouth Street (former EL Tahrir Street), Dokki, PO Box 12622, Giza, Egypt

${ }^{5}$ Department of Chemical Engineering, Loughborough University, Loughborough LE113TU, Leicestershire, UK

Submitted for consideration and publication in:

Journal of Pharmaceutical Sciences 


\begin{abstract}
Novel non-porous membranes were prepared by impregnating of nano-brushite and niobium pentoxide $\left(\mathrm{Nb}_{2} \mathrm{O}_{5}\right)$ into a gelatin/alginate matrix. The physicochemical properties, morphology and mechanical properties of the prepared membranes were characterized using XRD, FTIR, SEM, TEM and universal testing machine, respectively. Swelling ability of the prepared membranes was determined in distilled water. The surfaces of the membranes were characterized by means of FTIR and SEM coupled with EDX after submersion in simulated body fluid (SBF) up to 15 days. Moreover, the calcium and phosphorus ion concentrations in the SBF were measured by UV-spectrophotometer. The in vitro drug release and the release mechanism of a model antibiotic, namely, ciprofloxacin (CFX), were tested in phosphate buffer saline (PBS) for 15 days. The antibacterial activities of the CFX-loaded membranes were tested against known microorganisms. The physicochemical properties, morphology, mechanical properties and swelling ability of the prepared membranes were found to be dependent on the presence of $\mathrm{Nb}_{2} \mathrm{O}_{5}$ allowing control of their properties. For example, the $\mathrm{Nb}_{2} \mathrm{O}_{5}$-loaded membranes exhibited a higher in vitro bioactivity and slower drug release compared to those of $\mathrm{Nb}_{2} \mathrm{O}_{5}$-free membranes. The CFX-loaded membranes also exhibited an excellent inhibition zones against the selected microorganisms. Overall, the prepared membranes have been found to be very promising for use in bone substitute's applications.
\end{abstract}

Keywords: Niobium Pentoxide $\left(\mathrm{Nb}_{2} \mathrm{O}_{5}\right)$ Particulates; Nano-brushite; Gelatine/Alginate Membranes; Drug delivery.

\title{
1. Introduction
}

Guided tissue regeneration (GTR) is process in which a tissue defect is repaired or new tissue is reconstructed utilizing a barrier membrane (non-porous polymer matrix), which protects the defect site from the overrun/invasion of other tissue, especially fibrous connective tissue ${ }^{1}$. In its original form, GTR technique was established to be an operative procedure in periodontal therapy $y^{2,3,4,5}$. The safeguard offered by the membrane maintains the mesenchymal stem cells (MSCs) while allowing cell migration without any obstacles from the embracing periodontium. This enables a construction of new periodontal tissue, particularly precursor bone and periodontal ligament ${ }^{6}$. Two types of implant materials have been reported, namely, resorbable and non-resorbable materials. The resorbable material is 
replaced by the host tissue, and typically used as space filling implant. Non-resorbable materials are typically used as structural-support implant ${ }^{7,8}$.

The barrier membrane technique is generally utilized to guide bone regeneration in the bone defect site and the term of 'guided bone regeneration (GBR)'has been coined ${ }^{9,10}$. In the past twenty years, resorbable membranes have been investigated and introduced to GTR or GBR techniques. In recent years, resorbable membranes using materials such as chitosan $^{11}$, collagen ${ }^{12}$ and gelatin/alginate ${ }^{13}$ have gained a lot of attention in biomedical applications. However, these membranes possess some drawbacks due to their minimalmechanical strength and lake of physical stability. Therefore, incorporation of inorganic filler is needed to attain improved physico-chemical and mechanical properties for the resorbable membranes while GBR is applied.

With a view to finding optimal alternatives, various composite scaffolds and granules with multifunctional systems have been developed in previous studies ${ }^{14,15,16,17}$. Following the same idea, studies to develop resorbable GBR gelatine/alginate membranes has not been also reported.

Herein we aim to develop gelatin/alginate resorbable membranes (non-porous membrane) through in situ incorporation of nano-brushite as well as niobium pentoxide $\left(\mathrm{Nb}_{2} \mathrm{O}_{5}\right)$ powder in order to enhance their bioactivity and biodegradation. Nano-brushite is selected due to its impressive properties including biocompatibility, biodegradation and fast disillusion rate which are all very favorable for in vitro and in vivo biomineralization in the tissue $^{18}$. $\mathrm{Nb}_{2} \mathrm{O}_{5}$ system has shown certain promise as a nominee material for bioactive coatings on metallic implants ${ }^{19,20}$. Furthermore, the potential uses of these materials for medical implants are growing due to their impressive features such as high corrosion resistance and thermodynamic stability ${ }^{20,21}$. The osteoblasts preferentially adherence to the nano-sized $\mathrm{Nb}_{2} \mathrm{O}_{5}$ coatings roughness on polished $\mathrm{CP}$ titanium was studied by Eisenbarth et al. ${ }^{22}$ Accordingly, $\mathrm{Nb}_{2} \mathrm{O}_{5}$ particulate was selected to be loaded at different concentrations in gelatin/alginate membranes to improve the biocompatibility of the prepared systems. Moreover, physicochemical properties of the prepared membranes were determined by Xrays diffractometer (XRD) and Fourier-transform infrared spectroscopy(FTIR). The morphology of the prepared membranes was recorded by scanning electron microscopy (SEM) and transmission electron microscopy (TEM). Mechanical properties were measured by a universal testing machine. The experiments for determining swelling ability and in vitro biomineralization were conducted in distilled water and SBF, respectively. Finally, the drug delivery and release kinetics were determined in phosphate buffer saline (PBS).The 
antibacterial activities of an antibiotic, namely, ciprofloxacin (CFX) loaded membranes were also tested.

\section{Materials and experimental methods}

\subsection{Materials}

Gelatin from calf bone (Gel, medical grade, 280-320 bloom, type A), barium chloride $\left(\mathrm{BaCl}_{2}-2 \mathrm{H}_{2} \mathrm{O}\right)$ and low viscosity sodium alginate rich in a-L-guluronic residues (approximately $70 \%$ of G-block content) were obtained from Sigma-Aldrich, Germany. Niobium pentaoxide (99.5\%) was purchased from SPEX Industrial Inc., USA. The simulated body fluid (SBF) and phosphate buffer saline (PBS) were procured from SigmaAldrich. For the drug release studies polyvinylpyrrolidone (PVP) (molecular weight = 400000 g.mol ${ }^{-1}$ ) was purchased from Sigma-Aldrich, Germany, and ciprofloxacin (CFX) (molecular weight 331.34 g.mol-1 and $\geq 98.0 \%$ (HPLC)) was obtained from Fluka Analytical, Germany. All other chemicals for antimicrobial assay were purchased from Sigma-Aldrich, Germany.

\subsection{Preparation of nano-brushite}

Nano-brushite powder was synthesized by a chemical precipitation method reported earlier $^{23}$, briefly following the procedure as follows. $40.0 \mathrm{~g}$ of ammonium dihydrogen phosphate $\left(\mathrm{NH}_{4} \mathrm{H}_{2} \mathrm{PO}_{4}\right)$ was dissolved in distilled water $(340 \mathrm{~mL})$ at a $\mathrm{pH}$ value of 3.9. Thereafter, $10.0 \mathrm{~g}$ of calcite $\left(\mathrm{CaCO}_{3}\right)$ powder was added to the above solution at the room temperature $\left(25^{\circ} \mathrm{C}\right)$ and stirred for $30 \mathrm{~min}(500 \mathrm{rpm})$ at a $\mathrm{pH}$ 5.9. The precipitates formed at the end of the stirring were collected by filtration and washed with distilled water for several times. Subsequently, the obtained powder was dried in oven at $70^{\circ} \mathrm{C}$ to obtain $14.64 \mathrm{~g}$ of nano-brushite. The particulates in the powder have the water lily morphology ${ }^{23}$.

\subsection{Preparation of non-porous membranes}

The prepared nano-brushite was mixed with different ratios of niobium pentaoxide $\left(\mathrm{Nb}_{2} \mathrm{O}_{5} 99.5 \%\right)$. The mixtures were then loaded onto the polymeric matrix for synthesizing four different membranes as demonstrated in Table 1.

\section{INSERT TABLE 1}


The polymeric mixture was prepared by mixing equal ratios of gelatin and sodium alginate and stirred vigorously at $40^{\circ} \mathrm{C}$ in order to obtain a homogenized solution. Firstly, gelatin solution $(20 \% \mathrm{wt} / \mathrm{wt})$ and sodium alginate solution $(4 \% \mathrm{wt} / \mathrm{wt})$ were synthesized by dissolving the polysaccharide in distilled water at $40^{\circ} \mathrm{C}$. Thereafter, a fixed weight of the filler mixture $(3.5 \mathrm{~g})$ was blended with the polymer mixture and kept at $40^{\circ} \mathrm{C}$ in a water bath for $30 \mathrm{~min}$. Then, four mixtures of membrane were cast into petri dishes and kept at $4^{\circ} \mathrm{C}$. The hardened gels were further crosslinked by immersing in $\mathrm{BaCl}_{2}$ solution for $2 \mathrm{~h}$, and the non-reacted $\mathrm{BaCl}_{2}$ was eliminated by rinsing. After the cross-linking process, membranes with $10 \mathrm{~mm}$ diameter and $3 \mathrm{~mm}$ height were dried for $24 \mathrm{~h}$ at $50^{\circ} \mathrm{C}$. Preparation method of the $\mathrm{Nb}_{2} \mathrm{O}_{5}-$ loaded gelatin/alginate membranes is illustrated at Fig. 1.

\section{INSERT FIGURE 1}

\subsection{Physicochemical properties of the prepared membranes}

\subsubsection{Phase analysis}

In order to achieve information about the obtained phases for the prepared membranes before and after loading nano-brushite and $\mathrm{Nb}_{2} \mathrm{O}_{5}$ XRD measurements were conducted. The X-ray diffraction analyses were performed with the help of model D8 FOCUS Bruker, Germany with a $\theta-\theta$ goniometer (diameter $401 \mathrm{~mm}$ ), equipped with a $\mathrm{Cu}$ tube with excitation conditions of $36 \mathrm{~mA}$ and $45 \mathrm{kV}$, and a scintillation counter.

\subsubsection{Fourier transform infrared (FTIR) spectra of the prepared membranes}

FTIR spectra of the fabricated membranes were determined using $\mathrm{KBr}$ pellets containing membranes powder $(200: 2 \mathrm{Wt} / \mathrm{Wt}$ ratio). These pellets were scanned from 400 to $4000 \mathrm{~cm}^{-1}$ using a Nexus 670, Nicloet FTIR spectrometer.

\subsection{Particle morphology and size}

The particle morphology and size of the prepared nano-brushite were determined using SEM (SEM Model Philips XL 30 with accelerating voltage 30KV, England). Particle sample was mounted on stubs with adhesive carbon tape and sputter-coated by means of gold prior to assessment. Moreover, the particle morphology and size of the fillers within the membrane polymer matrix were recorded using TEM (JEM2010, Japan) operating at 200 $\mathrm{kV}$. 


\subsection{Mechanical properties}

Mechanical characterizations of the prepared membranes before and after $\mathrm{Nb}_{2} \mathrm{O}_{5}$ loading were studied utilizing a universal testing machine (Zwick Roell- Z0.5 TH Mechanical TestEquipment, Germany) equipped with a $1 \mathrm{kN}$ load cell. Membranes specimens of cross sectional area $20 \mathrm{~mm} \times 50 \mathrm{mmwere}$ tested by utilizing a gauge length of $25 \mathrm{~mm}$ and a crosshead speed of $2 \mathrm{~mm} / \mathrm{min}$. Five specimens of each membrane were analyzed for their tensile strength $(\mathrm{MPa})$, percentage elongation at break point $(\%)$ and Young's modulus (MPa). The above parameters were calculated by the following equations.

$$
\begin{aligned}
& T S=F_{\max } / A \\
& E(\%)=L / L_{o} \times 100
\end{aligned}
$$

where $F_{\max }$ corresponds to the maximum force $(\mathrm{N})$ at break point, $A$ is the cross-sectional area of the sample $\left(\mathrm{mm}^{2}\right), \mathrm{L}$ is the final length of the specimen at rupture, and $\mathrm{L}_{\mathrm{o}}(\mathrm{mm})$ is the original length of the membranes.

\subsection{Swelling behavior of the membranes}

The swelling capacity of the prepared membranes was estimated as follows. Rectangular specimens with size of $4 \times 6 \times 20 \mathrm{~mm}^{3}$ were used for the swelling tests in distilled water at $37^{\circ} \mathrm{C}$. After immersion for different periods $(3,6,9,12$, and 15 days), the specimens were taken away from the distilled water, the water excess was eliminated and weighted. Swelling percentage was estimated by equation (3).

$\operatorname{Sw}(\%)=\left(\frac{W_{f-} W_{i}}{W_{i}}\right) \times 100$

The initial weight of the specimen was recorded as $\mathrm{W}_{\mathrm{i}}$ and $\mathrm{W}_{\mathrm{f}}$ was the specimen weight after immersion. The experiment was carried out three times and the average value was taken in order to determine the result.

\subsection{In vitro biomineralization test}

\subsubsection{Surface characterization}

Bioactivity of the synthesized membranes was investigated after 15 days of immersion in SBF using FTIR and SEM coupled with energy dispersive X-ray analysis EDX in order to get better understanding for the membranes surface structures. 
According to the proposed method of Kokubo et al. ${ }^{24}$, the membranes were soaked in $\mathrm{SBF}$ at $37^{\circ} \mathrm{C}$ and $\mathrm{pH}=7.4$ at different time intervals. The $\mathrm{Ca}^{2+}$ and $\mathrm{P}^{+}$ions concentrations in the SBF were determined via UV-spectrophotometer (UV-2401PC, UV-VIS recording spectrophotometer, Shimadzu, Japan) utilizing biochemical kits (TechoDiagnostic, USA) at $\lambda=570 \mathrm{~nm}$ and at $\lambda=675 \mathrm{~nm}$, respectively, after immersion times.

\subsection{In vitro drug release}

One of the most common postoperative patient complications upon implantation of synthetic materials is the secondary infections. Therefore, it is highly recommended to incorporate bioactive molecules such as antibiotics into the implanted materials. Ciprofloxacin (CFX) antibiotic was loaded as a model drug to control infection when the membrane is used for GBR.

The membranes were loaded with CFX by dipping the samples into a $20 \% \mathrm{w} / \mathrm{v}$ PVP solution containing the drug. The quantity of loaded drug was ascertained by measuring the drug concentration before and after the dipping in the PVP solution. The solution was filtered, diluted with PBS, and analyzed by UV spectrophotometry. The in vitro CFX release was then studied in PBS at $\mathrm{pH} 7.4$ and temperature of $37^{\circ} \mathrm{C}$ as follows. Previously heated $50 \mathrm{~mL}$ of $\mathrm{PBS}$ (at $37^{\circ} \mathrm{C}$ ) was added to a glass vessels maintained at $37^{\circ} \mathrm{C}$ within an incubator. After different time intervals, $5 \mathrm{~mL}$ of the release medium were withdrawn and the concentration of CFX was determined spectrophotometrically at $277 \mathrm{~nm}$ using UV-Vis spectroscopy (Lambda 25 UV/Vis Spectrophotometer, PerkinElmer, Waltham, MA, USA).

\subsection{Mechanism of ciprofloxacin release}

Korsmeyer-Peppas model ${ }^{25}$ was used to find out the mechanism of drug release from the investigated membranes:

$$
\mathrm{M}_{t} / \mathrm{M}_{\infty}=\mathrm{Kt}^{\mathrm{n}}(4)
$$

where, $M_{t} / M_{\infty}$ is the fraction of drug released at time $t, k$ is the rate constant and $n$ is the release exponent. In case of quasi-Fickian diffusion the value of $\mathrm{n}<0.5$, Fickian diffusion $=0.5$, non-Fickian or anomalus transport $n=0.5-1.0$ and Case II transportn=1.0.

\subsection{Antimicrobial assay}

To confirm the efficacy of CFX-loaded membrane, the antibacterial activities of the synthesized membranes were tested using agar diffusion method ${ }^{26}$ against Escherichia coli Northern Regional Research Laboratory(NRRL) B-210 (Gram negative bacteria), Bacillus 
subtilis NRRL B-543 and Staphylococcus aureus NRRL B-313(Gram positive bacteria) subcultured into nutrient agar medium. The antifungal activity of these compounds was also tested against Candida albicans NRRL Y-477 using Sabouraud dextrose agar medium as follows. Suspension of $0.5 \mathrm{ml}$ of each of the aforementioned microorganisms was added to sterile nutrient agar media at $45^{\circ} \mathrm{C}$ and the mixture was transferred to sterile petri dishes and allowed to solidify.

Moreover, the membrane samples were cut into $0.5 \mathrm{~cm} \times 0.5 \mathrm{~cm}$ square pieces and placed on the surface of the solidified agar plates. The same method was performed using Sabouraud dextrose agar medium using Candida albicans NRRL Y-477. All plates were then incubated at $30^{\circ} \mathrm{C}$ for 24 hours and observed for antimicrobial activity. The diameters of inhibition zone were measured and compared with that of the standard antibiotics and the values were tabulated. Neomycin $(10 \mu \mathrm{g})$ and nalidixic acid $(30 \mu \mathrm{g})$ were used as standard for antibacterial and antifungal activity, respectively.

\section{Results and Discussion}

\subsection{Physicochemical properties of the prepared membranes}

\subsubsection{Phase analysis}

Fig. 2(a) shows the XRD patterns of the prepared membranes before and after $\mathrm{Nb}_{2} \mathrm{O}_{5}$ loading. The obtained XRD pattern of the prepared nano-brushite-loaded polymer matrix $\left(\mathrm{N}_{1}\right)$ possesses a fully crystalline composition. The diffraction peaks of the crystals are assigned to nano-brushite crystal structure (JCPDS file no. 2- 0085) XRD card at 11.63, $20.93,29.27,30,50,34,14,34.41,41.52$ and $50.172 \Theta$. No distinct peak of other phosphate phases was recorded. The intensity of the diffraction peaks indicates that the fillers were well crystallized.

The influence of $\mathrm{Nb}_{2} \mathrm{O}_{5}$ on the obtained phases was estimated by XRD analysis, XRD patterns of the membranes loaded with different percentages of $\mathrm{Nb}_{2} \mathrm{O}_{5}(\mathrm{~N} 2, \mathrm{~N} 3, \mathrm{~N} 4)$ were zoomed in the range (of 10 to 12) $2 \Theta$ as demonstrated in (Fig. 2(b)). The presence of $\mathrm{Nb}_{2} \mathrm{O}_{5}$ showed no characteristic peaks. However, there was a remarkable decrease in the intensity of the diffraction patterns. Consequently, the full width at half maximum decreased with the presence of $\mathrm{Nb}_{2} \mathrm{O}_{5}$ in the nano-brushite-loaded membranes, thus indicated the decrease of crystallinity and small particle size of the prepared membranes. The XRD results were consistence with the previously reported results ${ }^{27,28}$. However, no remarkable changes 
were observed for the nano-brushite-loaded membranes by increasing the $\mathrm{Nb}_{2} \mathrm{O}_{5}$. The $\mathrm{XRD}$ results revealed that the $\mathrm{Nb}_{2} \mathrm{O}_{5}$ showed no effect on the crystalline phase of the nanobrushite-loaded membranes, however, small decrease in intensity was observed.

\section{INSERT FIGURE 2}

\subsubsection{FTIR spectra of the prepared membranes}

The FTIR analyses are represented in Fig. 2c.Generally, all the prepared membranes exhibited bands at $873 \mathrm{~cm}^{-1}$ and $1225 \mathrm{~cm}^{-1}$ attributed to the $\mathrm{HPO}_{2}^{-4}$ group of nano-brushite. N1 possess clearly the characteristic bands of nano-brushite, thus bands were observed at wavelengths of around $525 \mathrm{~cm}^{-1}$ and $575 \mathrm{~cm}^{-1}$. These bands were assigned to the $v_{4}$ bending vibrations of the $\mathrm{P}-\mathrm{O}$ mode. The band at $985 \mathrm{~cm}^{-1}$ originates due to the $\mathrm{P}-\mathrm{O}(\mathrm{H}) v_{1}$ symmetric stretching vibration of $\mathrm{PO}_{3}{ }^{-4}$. Also, the band around $1060 \mathrm{~cm}^{-1}$ was assigned to the $v_{3}$ vibration of the $\mathrm{PO}_{3}^{-4}$ group. Another band was observed close to $1134 \mathrm{~cm}^{-1}$, which was assigned to the $v_{6}$ and $v_{6}$ degeneration stretch of $\mathrm{HPO}_{2}^{-4}$ ions in nano-brushite. The four sharp characteristics bands between $870 \mathrm{~cm}^{-1}$ and $1150 \mathrm{~cm}^{-1}$ were assigned to the $\mathrm{P}-\mathrm{O} / \mathrm{P}-$ $\mathrm{O}(\mathrm{H})$ stretching as previously reported ${ }^{29,30}$.

The FTIR spectra revealed that the observed bands were similar with those of nanobrushite. For the $\mathrm{Nb}_{2} \mathrm{O}_{5}$-loaded membranes, remarkable changes were observed as follows. Disappearance of band at $3412 \mathrm{~cm}^{-1}$ that was attributed to the $\mathrm{OH}$ stretching suggested the formation of $\mathrm{Nb}-\mathrm{OH}$ group, the exemplary band was observed at $3140 \mathrm{~cm}^{-1}$ owing to the hydroxyl stretching. Moreover, a wide band was noted at $1637 \mathrm{~cm}^{-1}$ according to adsorbed water on the $\mathrm{Nb}_{2} \mathrm{O}_{5}$ surface, also the band at $870 \mathrm{~cm}^{-1}$ that was assigned to $\mathrm{Nb}-\mathrm{O}$ stretching and bands at 500 and $950 \mathrm{~cm}^{-1}$ were assigned to $\mathrm{Nb}-\mathrm{O}-\mathrm{Nb}$ angular vibrations also can be observed. Furthermore, the band at approximately $537 \mathrm{~cm}^{-1}$ was also detected, this band due to O-O type asymmetrical stretching bonded to the metal $(\mathrm{Nb}-\mathrm{O})$ and even at $820-870 \mathrm{~cm}^{-1}$ assigned to the O-O stretching ${ }^{31,32,33}$.

Furthermore, different bands were obtained for $\mathrm{N}_{2}$ and $\mathrm{N}_{3}$. The stretching bands of internal hydroxyls were observed at $3202 \mathrm{~cm}^{-1}$ and at $3488 \mathrm{~cm}^{-1}$, these bands were also observed in the $\mathrm{N}_{4}$ membrane. The aforementioned bands were more pronounced in the broad spectra of nano-brushite and $\mathrm{Nb}_{2} \mathrm{O}_{5}$ into the polymer matrix, compared to those of $\mathrm{N} 1$ membrane. A strong band was obtained at $1696 \mathrm{~cm}^{-1}$ regarding the angular deformation of $\mathrm{O}-\mathrm{H}$ of $\mathrm{H}_{2} \mathrm{O}$ adsorbed or adhered to the surface of N4. FTIR results confirmed the impregnation $\mathrm{ofNb}_{2} \mathrm{O}_{5}$ into the membrane polymer matrix and in line with earlier reported studies $^{31,32,33,34}$. 


\subsection{Morphology and Size}

The morphology of pure nano-brushite filler was investigated by SEM. As illustrated from Fig. 3(a), the prepared nano-brushite exhibited floral-like nanostructures with diameters ranging from 100 to $244 \mathrm{~nm}$. It is worthwhile to note that the symmetrical agglomeration of nano-brushite semi-needles was due to the strong attraction force of the layered structure to the particles, which in turn induced the formation of nano-brushite symmetrical agglomeration morphology. Furthermore, the semi-needles morphology consists of similar petal-like flakes growing radically from the centre. SEM image confirmed the XRD results that indicate smaller grain sizes of nano-brushite filler. These results indicate that the medium reagents for precipitation have a strong effect on the crystal structure of nano-brushite as early reported for phosphate ceramic synthesis ${ }^{35}$.

\section{INSERT FIGURE 3}

Moreover, to determine the effect of $\mathrm{Nb}_{2} \mathrm{O}_{5}$ on the dispersion behavior of the nano-brushite filler into the polymer matrix, TEM micrographs were recorded for N2, N3 and N4 as illustrated in Fig. 3(b, c and d). All the micrographs showed crystalline aggregates of nanobrushite within the prepared membranes. The influence of $\mathrm{Nb}_{2} \mathrm{O}_{5}$ to nano-brushite on the microstructure was obvious, the higher $\mathrm{Nb}_{2} \mathrm{O}_{2}$ the bigger dispersed particles ${ }^{35,36}$. The prepared fillers exhibited defined small crystalline particles (Fig. 3(b, c)), ranging between 100 and 200nm, while clearly defined large crystalline particles with a broad size ranging from 1 to $2 \mu \mathrm{m}$ were obtained for filler within N4 (Fig. 3(d)).

\subsection{Mechanical properties}

Controlling and understanding mechanical properties are conclusive needs for guided bone regeneration. To determine the effect of the incorporated $\mathrm{Nb}_{2} \mathrm{O}_{2}$ into the prepared membranes on the physico-mechanical properties, mechanical performance of the membranes was studied by measuring tensile strength, elongation at break point and Young's modulus ${ }^{36}$. All the prepared membranes showed impressive mechanical properties as illustrated at Fig. 3 (e, f and g). The $\mathrm{Nb}_{2} \mathrm{O}_{5}$-loaded membranes possessed the maximum mechanical values (74MPa, 6.7\% and $1980 \mathrm{MPa}$ ) for tensile strength, elongation at break and Young's modulus, respectively. These results are attributed to the presence of $\mathrm{Nb}_{2} \mathrm{O}_{5}$. In addition, the incorporation of the $\mathrm{Nb}_{2} \mathrm{O}_{5}$ into the polymer matrix showed no significant influence on Young's modulus of the membranes as demonstrated in Fig. 3g. According to the results, it can be confirmed that $\mathrm{Nb}_{2} \mathrm{O}_{5}$-loaded membranes holds the maximum 
mechanical performance compared to the $\mathrm{Nb}_{2} \mathrm{O}_{5}$-free membranes. It is worthwhile to highlight that enhanced mechanical properties would protect the integrity of the membranes and would enable it to induce bone formation without any physico-mechanical deformations ${ }^{38,39}$.

\subsection{Swelling behavior of membranes}

As illustrated in Fig. 4a, the swelling percentage was found to be dependent on the soaking time in the distilled water. Particularly, the swelling percentage increased with the increase of the soaking time. However, the swelling rate becomes slower after long soaking time due to reaching the saturation state. It is worthwhile to note that the swelling percentage decreased with increased $\mathrm{Nb}_{2} \mathrm{O}_{5}$ weight \%. This result could be due to the possible interaction between $\mathrm{OH}$ of the gelatin/alginate polymer matrix with the $\mathrm{OH}$ groups of nano-brushite or $\mathrm{Nb}_{2} \mathrm{O}_{5}$, which decreased the free $\mathrm{OH}$ content in the membrane. Therefore, a reduction of the hydrophilic properties for all membranes would be expected. This result confirmed that the $\mathrm{Nb}_{2} \mathrm{O}_{5}$ had enhanced the membrane stability in distilled water when compared with $\mathrm{Nb}_{2} \mathrm{O}_{5}$-free membranes. The results indicated that the fabricated membranes are capable of absorbing large amounts of water that would induce a better attachment for the surrounding cells into the membrane matrix ${ }^{40}$.

\subsection{In vitrobio-mineralization test}

\subsubsection{Surface characterization}

FTIR spectra of $\mathrm{Nb}_{2} \mathrm{O}_{5}$-free and loaded membranes are illustrated in Fig. 4 (b, c, d and e) before and post immersion in SBF for several durations. The prepared membranes before and after soaking in SBF for 9 and 15 days confirmed the formation of carbonated apatite deposition onto the membrane surfaces. Generally, all the prepared membranes exhibited the formation of new bands at 460, 863, 965 and $1094 \mathrm{~cm}^{-1}$ corresponding to $\mathrm{PO}_{4}{ }^{-3}$ and PO, respectively, and the intensity of these bands increased with increased immersion time similar results were reported $\mathrm{by}^{41,42}$. In addition, the intensity of the carbonates bands at 1430 and $1630 \mathrm{~cm}^{-1}$ attributed to $\mathrm{C}-\mathrm{O}$ and $\mathrm{C}=\mathrm{O}$, respectively, were increased after soaking in SBF. The FTIR results revealed that the $\mathrm{Nb}_{2} \mathrm{O}_{5}$ presence has a significant effect on the biolayer formation as confirmed by the HA groups onto the membrane surfaces such as phosphate (bending and stretching) and $\mathrm{OH}$ groups were slightly increased after immersion in SBF compared to $\mathrm{Nb}_{2} \mathrm{O}_{5}$-free membranes especially after 9 days. 


\section{INSERT FIGURE 4}

The SEM images of the prepared membranes before and after immersion as well as EDX of membranes surfaces after immersion in SBF are given in Fig. 5.The surface morphology of the prepared $\mathrm{Nb}_{2} \mathrm{O}_{5}$-free membrane showed a rough structure with some nano-platelets structure as illustrated at Fig. 5 ( $a, b, c$ and d). The nanofillers were observed as agglomerates incorporated within the polymer matrix. However, the microstructure of the membrane N3exhibited close, adhered and impressive interfacial attachment between the matrix and the filler, without observation of any cracks or voids in the interface of the components. Furthermore, the microstructures of the membrane $\mathrm{N}_{4}$ exhibitedexcellent dispersion of the nano-fillers in the matrix and good interfacial bonding between the polymer and the nano-fillers. These results confirmed that the presence of $\mathrm{Nb}_{2} \mathrm{O}_{5}$ had enhanced the dispersion of the nano-filler into the polymer matrix, which is in the same line with TEM results see (Fig. 2(b, c and d)).

The surface of N1 after immersion in SBF showed remarkable changes due to the biodegradation. In addition, a thin layer of precipitated crystals was observed on the membrane surfaces showed in Fig. 5e. Also, there was some dense bright layer onto the surface, confirming faster apatite nucleation. The EDX result recorded small $\mathrm{Ca} / \mathrm{P}$ ratio $(0.9)$ as showed in Fig. 5i, which is lower than the deficient hydroxyapatite formation (1.67) for after immersion.

\section{INSERT FIGURE 5}

For membrane $\mathrm{N}_{2}$, Fig. $5 \mathrm{f}$ showed the occurrence of rough surface including small and large precipitated particles onto the membrane $\mathrm{N}_{2}$ surface confirming the formation of apatite layer. Also, EDX analysis proved that the precipitated apatite layer on the membrane $\mathrm{N}_{2}$ surface (1.45) was enhanced compared to membrane N1 Fig. 5j. The result proved that the existence of $\mathrm{Nb}_{2} \mathrm{O}_{5}$ within the polymer matrix enhanced the degree of calcium phosphate precipitation.

SEM coupled with EDX (Ca/P:1.64) Fig. 5 (g and k) of N3 after immersion in SBF exhibited a rough surface with bright longitudinal nodes proved the bio-deposition of bone like apatite. Also, the existence of concentrated global structure with bright color and some corrosion were observed. Thus, this confirmed the precipitation of bone-like apatite layer. On the other side the SEM coupled with EDX analysis Fig. $5(\mathrm{~h}, 1)$ of N4 surface proved that the deposited apatite layer on the membrane (1.67) was enhanced compared to other 
membranes, and the $\mathrm{Ca} / \mathrm{P}$ ratio is typically the same as the hydroxyapatite ratio $(\mathrm{Ca} / \mathrm{P}: 1.67)^{43}$. These results confirmed that the higher $\mathrm{Nb}_{2} \mathrm{O}_{5}$ into the polymer matrix the higher calcium phosphate precipitations.

\subsubsection{Ions concentration in $\mathrm{SBF}$}

Fig. 6(a, b and c) depicts the release of $\mathrm{Ca}^{2+}, \mathrm{P}^{+}$ions in $\mathrm{SBF}$ and the $\mathrm{Ca} / \mathrm{P}$ ratio up to 15 days for all the prepared membranes. The $\mathrm{Nb}_{2} \mathrm{O}_{5}$-loaded membranes recorded low values of $\mathrm{Ca}^{2+}$ ions concentration in SBF $(43.04 \% \pm 0.50,41.54 \pm 0.56 \%$ and $31.39 \pm 0.67 \%)$ compared to $\mathrm{Nb}_{2} \mathrm{O}_{5}$-free membranes $(44.04 \% \pm 0.85)$ as showed in Fig. 6a. These results suggested a higher $\mathrm{Ca}^{2+}$ ions deposition on the surfaces of $\mathrm{Nb}_{2} \mathrm{O}_{5}$-loaded membranes. Similarly, lower values of $\mathrm{P}^{+}$ions concentration were recorded for the $\mathrm{Nb}_{2} \mathrm{O}_{5}$-loaded membranes $(25.90 \pm 0.45 \%, 28.00 \% \pm 1.2$ and $32.25 \% \pm 0.9)$ compared to the $\mathrm{Nb}_{2} \mathrm{O}_{5}$-free membranes $(45.50 \% \pm 01.5)$ as showed in Fig. $6 \mathrm{~b}$. The results suggested that the calcium phosphate layer would be greater on the surface of the $\mathrm{Nb}_{2} \mathrm{O}_{5}$-loaded membranes as confirmed by SEM coupled with EDX results.

The material with potential bioactivity could be in vitro analyzed in SBF, because it is much cheaper and quicker than other in vitro methods. It could provide evidences for understanding of the basic principle of interaction between bone and biomaterials ${ }^{40,41}$. The implication of the present results on biolayer formation is predicted through calculating the ratio $\mathrm{Ca}^{2+} / \mathrm{P}^{+}$for each immersion period of the membranes with various concentrations as showed in Fig. 6c. It is worthy to highlight that the values of $\mathrm{Ca}^{2+} / \mathrm{P}^{+}$ratio higher than 1.6, indicated the precipitation of crystalline apatite structure on the surface of biomaterial according to our previous work ${ }^{43}$.

\section{INSERT FIGURE 6}

\subsection{In vitro drug release}

To study the influence of $\mathrm{Nb}_{2} \mathrm{O}_{5}$ loading on the CFX release attitude, in vitro drug release studies were carried out for all CFX-loaded membranes in PBS as shown in Fig. 6d. Generally, all the membranes released $15 \%$ of CFX after $24 \mathrm{~h}$, afterwards, the release behavior followed linear pattern up to $360 \mathrm{~h}$. CFX release from both $\mathrm{Nb}_{2} \mathrm{O}_{5}$-loaded and $\mathrm{Nb}_{2} \mathrm{O}_{5}$-free membranes was comparatively similar except that the final linear phase from the $\mathrm{Nb}_{2} \mathrm{O}_{5}$-containing membranes was slightly decreased $(5 \%)$ and the presence of $\mathrm{Nb}_{2} \mathrm{O}_{5}$ clearly down-regulated the CFX release rates. 
These results were based on the fact that CFX was incorporated into the gelatin/alginate polymer matrix through physical dipping into PVP solution that contains CFX as early mentioned in the methodology section. Therefore the CFX was superficially adsorbed onto the $\mathrm{Nb}_{2} \mathrm{O}_{5}$-free membranes matrices. The moment that bared to PBS solution the physical bond between CFX and the gelatin/alginate polymer matrix was easily detached due to the hydrophilicity of both PVP and CFX, leading to a significant initial release phase followed by linear behavior up to $360 \mathrm{~h}$. In contrast, the presence of $\mathrm{Nb}_{2} \mathrm{O}_{5}$ formed hydrogen bonding with CFX which relatively decreased the final linear phase of CFX from the $\mathrm{Nb}_{2} \mathrm{O}_{5}-$ loaded membranes. These results were in the line with earlier reported results for sustained drug release from multi-phase blend scaffolds ${ }^{41,44}$. In summary, the higher quantities of $\mathrm{Nb}_{2} \mathrm{O}_{5}$ regulated the release profiles of CFX from the membranes.

\subsection{Mechanism of ciprofloxacin release}

The in vitro kinetic release of CFX followed diffusion kinetics with $\mathrm{r}$ (correlation coefficient) above $0.98^{45}$. The in vitro kinetic release parameters are summarized in Table 2 . The CFX release behavior was slower in the case of all $\mathrm{Nb}_{2} \mathrm{O}_{5}$-loaded membranes when compared to $\mathrm{Nb}_{2} \mathrm{O}_{5}$-free membranes. However, a small quantity of CFX was released at first from the membranes after little time, at which point the release behavior was found to be constant, thus the obtained curves remained plateau until the end of the study. The $\mathrm{Nb}_{2} \mathrm{O}_{5}-$ loaded membranes were capable to absorb more free-CFX compared to the $\mathrm{Nb}_{2} \mathrm{O}_{5}$-free membranes, but no impulse release of the antibiotic was observed while the presence of $\mathrm{Nb}_{2} \mathrm{O}_{5}$ relatively controlled the CFX release. Thus, we can conclude that the CFX released is comparatively controlled by the $\mathrm{Nb}_{2} \mathrm{O}_{5}$ percentage.

\section{INSERT TABLE 2}

\subsection{Antimicrobial assay}

The inhibition zones of CFX-loaded membranes against the Gram positive bacteria (Bacillus subtilis and Staphylococcus aureus), Gram negative bacteria (Escherichia coli) and Fungi (Candida albicans) were measured using the disc diffusion method according as early reported by Mabrouk et al. [46].All CFX-loaded membranes exhibited great activity against the selected microorganisms. These results were only observed for the CFX-loaded membranes. The CFX-free membranes did not show any antibacterial activity against the same under investigated microorganisms as demonstrated in Fig. 6 (e, f, g and h). This result confirmed the antibacterial activity of the CFX antibiotic as previously reported [42]. 


\section{INSERT TABLE 3}

\section{Conclusions}

Multifunctional membranes were fabricated in order to guarantee better physicochemical-mechanical properties, bioactivity and drug delivery through incorporation of $\mathrm{Nb}_{2} \mathrm{O}_{5}$ as well as nano-brushite. Swelling ability of the membranes was better controlled due to the presence of $\mathrm{Nb}_{2} \mathrm{O}_{5}$, which in turn provides better stability control in the physiological media (SBF). The in vitro biomineralization confirmed that the presence of $\mathrm{Nb}_{2} \mathrm{O}_{5}$ within polymer matrix had led to a remarkable enhancement on the formation of the apatite layer. It was found that the $\mathrm{Ca} / \mathrm{P}$ ratio (1.5-1.6) was very close to that of the bone HA (1.67). Moreover, the drug delivering ability of prepared systems also confirmed and the in vitro release behavior followed the first order kinetic mechanism. Furthermore, The CFX antibacterial activity was confirmed for the CFX loaded membranes against the selected microorganisms. Finally, novel membranes with unique bioactivity, mechanical properties, drug delivering ability and antibacterial activity are highly recommended to be applied in bone regeneration as GBR.

\section{Future aspects}

The prepared membranes will be tested against normal osteoblast cells to get more data in order to clarify the relationship between the membrane and cells (e.g., osteoinductivity, osteoblast differentiation markers RunX2, osteocalcin, ALP activity).

\section{References}

1. Dahlin C, Sennerby L, Lekholm U, Linde A, Nyman S.1989. Generation of new bone around titanium implants using a membrane technique: An experimental study in rabbits, Int. J. Oral Maxillofac. Implants. 4: 19-25.

2. Moses O, Pitaru S, Artzi Z, Nemcovsky CE.2005. Healing of dehiscence-type defects in implants placed together with different barrier membranes: A comparative clinical study, Clin. Oral Implants Res. 16: 210-219.

3. Lee J-Y, Lee J, Kim Y-K. 2013. Comparative analysis of guided bone regeneration using autogenous tooth bone graft material with and without resorbable membrane, J. Dent. Sci. 8: 281-286. 
4. Beitlitum I, Artzi Z, CE. 2010. Nemcovsky, Clinical evaluation of particulate allogeneic with and without autogenous bone grafts and resorbable collagen membranes for bone augmentation of atrophic alveolar ridges: Bone augmentation with allo- and autografts and collagen membrane, Clin. Oral Implants Res. 2: 1242-1250.

5. Retzepi M, Donos N. 2010. Guided bone regeneration: Biological principle and therapeutic applications. Clin. Oral Implants Res. 21 (2010) 567-576.

6. Dimitriou R, Mataliotakis GI, Calori GM, Giannoudis PV. 2012. The role of barrier membranes for guided bone regeneration and restoration of large bone defects: Current experimental and clinical evidence, BMC Med. 10: 1-24.

7. Sowmya S, Bumgardener JD, Chennazhi KP, Nair SV, Jayakumar R. 2013. Role of nanostructured biopolymers and bioceramics in enamel, dentin and periodontal tissue regeneration, Prog. Polym. Sci. 38: 1748-1772.

8. Braddock M, Houston P, Campbell C, Ashcroft P. 2001. Born Again Bone: Tissue Engineering for Bone Repair, News Physiol. Sci. 16: 208-213.

9. Cai Y, Guo J, Chen C, Yao C, Chung S-M, Yao J, Lee I-S, Kong X. 2017. Silk fibroin membrane used for guided bone tissue regeneration, Materials Science and Engineering C 70: $148-154$.

10. Malmström J, Anderudl J, Abrahamsson P, Wälivaara D-À, Isaksson SG, Adolfsson E. 2016. Guided bone regeneration using individualized ceramic sheets, Int. J. Oral Maxillofac. Surg. 45: 1246-1252.

11. Lee B-S, Lee C-C, Lin H-P, Shih W-A, Hsieh W-L, Lai C-H, Takeuchi Y, Chen Y-W. 2016. A functional chitosan membrane with grafted epigallocatechin-3-gallate and lovastatin enhances periodontal tissue regeneration in dogs, Carbohydrate Polymers 151: 790-802.

12. Hadzik J, Kubasiewicz-Ross P, Kunert-Keil C, Jurczyszyn K, Nawrot-Hadzik I, M. Dominiak, Gedrange T. 2016. A silver carp skin derived collagen in bone defect treatment-Ahistological study in a rat model, Annals of Anatomy 208: 123-128.

13. Graulus G-J, Mignon A, Vlierberghe SV, Declercq H, Fehér K, Cornelissen M, Martins JC, Dubruel P. 2015. Cross-linkable alginate-graft-gelatin copolymers for tissue engineering applications, European Polymer Journal 72: 494-506.

14. Sharma C, Dinda AK, Potdar PD, Chou C-F, Mishra NC. 2016. Fabrication and characterization of novel nano-biocomposite scaffold of chitosan-gelatin-alginatehydroxyapatite for bone tissue engineering, Materials Science and Engineering C. 64: 416-427. 
15. Sarker A, Amirian J, Min YK, Lee BT. 2015. HAp granules encapsulated oxidized alginate-gelatin-biphasiccalcium phosphate hydrogel for bone regeneration. International Journal of Biological Macromolecules 81: 898-911.

16. Dong Z, Wang Q, Du Y. 2006. Alginate/gelatin blend films and their properties for drug controlled release, Journal of Membrane Science 280: 37-44.

17. Li Y, Jia H, Cheng Q, Pan F, Jiang Z. 2011. Sodium alginate-gelatin polyelectrolyte complex membranes with both high water vapor permeance and high permselectivity, Journal of Membrane Science 375: 304-312.

18. Kodaka T, Kobori M, Hirayama A, Abe M. 1999. Abrasion of human enamel by brushing with a commercial dentifrice containing hydroxyapatite crystals in vitro, Journal of Electron Microscopy. 48: 167-172.

19. Olivares-Navarrete R, Olaya JJ, Ramírez C, Rodil SE. 2011. Biocompatibility of niobium coatings, Coatings;1 (1): 72-87.

20. Ramírez G, Rodil SE, Muhl S, Turcio-Ortega D, Olaya JJ, Rivera M, Camps E, Escobar-Alarcón L. 2010. Amorphous niobium oxide thin films, J. Non-Cryst. Solids 356 (50-51): 2714-2721.

21. Nascimento WJ, Bonadio TGM, Freitas VF, Weinand WR, Baesso ML, Lima WM. 2011. Nanostructured $\mathrm{Nb}_{2} \mathrm{O}_{5}$-natural hydroxyapatite formed by the mechanical alloying method: a bulk composite, Mater. Chem. Phys. 130 (1-2): 84-89.

22. Eisenbarth E, et al. 2006. Nanostructured niobium oxide coatings influence osteoblast adhesion, Journal of Biomedical Materials Research Part A. 79A (1): 166-175.

23. Berry EE, \& Baddiel CB. 1967. The infra-red spectrum of dicalcium phosphate dihydrate (brushite), Spectrochimica Acta Part A: Molecular Spectroscopy 23: 20892097.

24. Kokubo T, Takadama H. 2006. How useful is SBF in predicting in vivo bone bioactivity?, Biomaterials 27: 2907-2915.

25. Korsmeyer RW and Peppas NA. 1983. in: Mansdorf SZ and Roseman TJ (Eds.). Controlled Release Systems, Marcel Dekker, New York, p. 77.

26. Cruickshank R, Duguid JP, Marion BP, Swain RHA. 1975. Medicinal Microbiology, twelfth ed., vol. II, Churchill Livingstone, London, pp. 196-202.

27. Suryanarayana C. 2001. Mechanical alloying and milling, Prog. Mater. Sci. 46: 39.

28. Nascimento WJ, Bonadio TGM, Freitas VF, Weinand WR, Baesso ML, Lima WM. 2011. Nanostructured $\mathrm{Nb}_{2} \mathrm{O}_{5}$-natural hydroxyapatite formed by the mechanical alloying method: A bulk composite, Materials Chemistry and Physics 130: 84-89. 
29. Pennel G, Leroy G, Rey C, Sombret B, Huvenne JP, Bres E. 1997. Infrared and Raman microspectrometry study of fluoro-fluoro-hydroxy and hydroxy-apatite powders, Journal of Material Science: Materials in Medicine. 8: 271- 276.

30. Wang J, Fu W, Zhang D, Yu X, Li J, Wan C. 2010. Evaluation of novel alginate dialdehyde cross-linked chitosan/calcium polyphosphate composite scaffolds for meniscus tissue engineering, Carbohydrate Polymers 79: 705-710.

31. Prasetyoko D, Ramli Z, Endud S, Nur H. 2005. Preparation and characterization of bifunctional oxidative and acidic catalysts $\mathrm{Nb}_{2} \mathrm{O}_{5} / \mathrm{TS}-1$ for synthesis of diols, Materials Chemistry and Physics 93: 443-449.

32. Marco P and Lorens J. 2007. Understanding of naphthalene sulfonate formaldehyde condensates as a dispersing agent to stabilise raw porcelain gres suspensions: Surface adsorption and rheological behaviour, Colloids \& Surfaces A, 299 (1-3): 180-185.

33. Colthup N, Daly L, Wiberley S. 1975. Introduction to infrared and Raman spectroscopy. Academic Press, New York.

34. Goncalves M, Oliveira L, Guerreiro M. 2008. Magnetic niobia as adsorbent of organic contaminants in aqueous medium: effect of temperature and pH, Quim. Nova 31: 518.

35. Pradhan D, Wren AW, Misture ST, Mellott NP. 2016. Investigating the structure and biocompatibility of niobiumand titanium oxides as coatings for orthopedic metallic implants, Materials Science and Engineering C. 58: 918-926.

36. Pauline SA, and Rajendran N. 2014. Biomimetic novel nanoporous niobium oxide coating for orthopaedic applications, Applied Surface Science 290: 448- 457.

37. Cuppoletti J. 2011. Metal, ceramic and polymeric composites for various uses. InS. M. Mousavinasab (Ed.), Effects of filler content on mechanical and optical properties of dental composite resins. Shanghai, China: InTech.

38. Liu X, Wang T, Chow LC, Yang M, Mitchell JW. 2014. Effects of inorganic fillers on the thermal and mechanical properties of poly(lactic acid), International Journal of Polymer Science 2014: 1-8.

39. Rubab Z, Afzal A, Siddiqi HM, Saeed S. 2014. Preparation, characterization :and enhanced thermal and mechanical properties of epoxy-titania composites, The Scientific World Journal 2014: 1-7.

40. Vlierberghe SV, Dubruel P, Schacht E. 2011. Biopolymer-Based Hydrogels As Scaffolds for Tissue Engineering Applications: A Review. Biomacromolecules 12(5): 1387-1408. 
41. Mabrouk M, Choonara YE, Kumar P, Toit LC du, Pillay V. 2016. Effect of Lyophilized EmuGel Silica Microspheres on the Physicomechanical Properties, In Vitro Bioactivity and Biodegradation of a Novel Ciprofloxacin-Loaded PCL/PAA blend Scaffold, Polymers 8 : 232; doi:10.3390/polym8060232.

42. Mabrouk M, Choonara YE, Marimuthu T, Kumar P, Toit LC du, Vuuren SV, Pillay V. 2016. $\mathrm{Ca}_{3}\left(\mathrm{PO}_{4}\right)_{2}$ Precipitated Layering of an In Situ Hybridized PVA/Ca $2 \mathrm{O}_{4} \mathrm{Si}$ NanoFibrous Antibacterial Wound Dressing, International Journal of Pharmaceutics 507: 41-49.

43. Boulila S, Oudadesse H, Badraoui R, Lefeuvre B, Mabrouk M, Chaabouni K, Mostafa A, Makni-Ayedi F, Barroug A, Rebai T, Elfeki A, Elfek H. 2016. Antioxidative/oxidative effects and retarding osteoconductivity of ciprofloxacinloaded porous polyvinyl alcohol/bioactive glass hybrid. Med Biol Eng Comput. doi 10.1007/s11517-016-1473-1.

44. Mabrouk M, Mulla JAS, Kumar P, Chejara DR, Badhe RV, Choonara YE, Toit LC du, Pillay V. 2015. Intestinal Targeting of Ganciclovir Release Employing a Novel HEC-PAA Blended Lyomatrix, AAPS Pharm Sci Tech, doi: 10.1208/s12249-0150442-6.

45. Ashfaq M, Khan S, Verma N. 2014. Synthesis of PVA-CAP-based biomaterial in situ dispersed with $\mathrm{Cu}$ nanoparticles and carbon micro-nanofibers for antibiotic drug delivery applications, Biochemical Engineering Journal 90: 79-89.

46. Mabrouk M, Selim MM, Beherei H, and El Gohary MI. 2013. Incorporation Effect of silver and zinc-zeolites into commercial Glass Ionomer Cement. Interceram 62 (1): 50 54.

\section{Figures Caption}

Fig. 1. Preparation method of the $\mathrm{Nb}_{2} \mathrm{O}_{5}$-loaded gelatin/alginate membranes. 
Fig. 2. Illustrations of a) XRD spectra of N2, N3 and N4 with reference to N1 (5-60) 2Ө, b) $(10-12) 2 \Theta$ and c) FTIR spectra of N2, N3 and N4 with reference to N1.

Fig. 3. Illustration of a) SEM of the nano-brushite; TEM images of b)N2, c)N3 and d) N4 and, mechanical measurements e) tensile strength, f) elongation at break point and $\mathrm{g}$ ) Young's modulus of the prepared membranes.

Fig. 4. Demonstration of $\mathrm{s}$ the swelling (\%) in distilled water at $\mathrm{pH} 7.4$ and incubation temperature of $37^{\circ} \mathrm{C}$; FTIR spectra of the prepared membranes b) N1, c) N2, d) N3 and e) N4 before and after immersion in SBF for different time intervals.

Fig. 5. SEM images of the developed non-membrane porous surfaces of a) N1, b) N2, c) N3 and d) N4 as prepared; SEM images of e) N1, f) N2, g) N3 and h) N4 coupled with EDX i) $\mathrm{N} 1, \mathrm{j}) \mathrm{N} 2, \mathrm{k}$ ) N3 and 1) N4 after 15 days of immersion in SBF.

Fig. 6. Illustrations of a) $\mathrm{Ca}$, b) $\mathrm{P}$ ions concentration in $\mathrm{SBF}$ and the c) $\mathrm{Ca} / \mathrm{P}$ ratio up to 15 days of immersion; d) cumulative CFX (\%) release in PBS up to 360 hours (15 days) using agar diffusion method e) Staphylococcus aureus, f) Candida albicans, g) Bacillus subtilis and h) Escherichia coli with reference to Neomycin antibiotic. 
Table 1. Formulation template of nano-brushite and $\mathrm{Nb}_{2} \mathrm{O}_{5}$-loaded membranes based on the filler weight $\%$.

\begin{tabular}{ccccc}
\hline SN & Membrane code & $\begin{array}{c}\text { Nano-brushite } \\
(\% \text { wt/wt) }\end{array}$ & $\begin{array}{c}\text { polymermatrix } \\
(\% \text { wt/wt })\end{array}$ & $\begin{array}{c}\mathbf{N b}_{2} \mathrm{O}_{5} \\
(\% \mathbf{w t} / \mathbf{w t})\end{array}$ \\
\hline $\mathbf{1}$ & $\mathbf{N 1}$ & 20 & 80 & 0 \\
$\mathbf{2}$ & $\mathbf{N} 2$ & 18 & 80 & 2 \\
$\mathbf{3}$ & $\mathbf{N 3}$ & 16 & 80 & 4 \\
$\mathbf{4}$ & $\mathbf{N 4}$ & 12 & 80 & 8 \\
\hline
\end{tabular}


Table 2. In vitro kinetic release of $\mathrm{CFX}$ from and $\mathrm{Nb}_{2} \mathrm{O}_{5}$ - loaded membranes

\begin{tabular}{|c|c|c|c|c|c|c|c|}
\hline & & $\overline{R^{2} \text {-va }}$ & & First & order & $\mathrm{n}$ & RE 0- \\
\hline $\begin{array}{r}\text { Formula } \\
\text { code }\end{array}$ & $\begin{array}{l}\text { Zero- } \\
\text { order }\end{array}$ & $\begin{array}{l}\text { First- } \\
\text { order }\end{array}$ & $\begin{array}{c}\text { Korsmeyer- } \\
\text { Peppas } \\
\text { model }\end{array}$ & $\begin{array}{c}\text { t50* }^{*} \\
\text { (hours) }\end{array}$ & $\begin{array}{c}\text { t90 } * * \\
\text { (hours) }\end{array}$ & & $\begin{array}{l}360 \mathrm{~h}^{\ddagger} \\
(\%)\end{array}$ \\
\hline N1 & 0,958 & 0,991 & 0,883 & 432,926 & 1528,135 & 2,187 & 45,455 \\
\hline N2 & 0,956 & 0,989 & 0,866 & 490,675 & 1728,535 & 2,059 & 43,176 \\
\hline N3 & 0,938 & 0,983 & 0,855 & 587,283 & 2077,505 & 1,873 & 37,575 \\
\hline N4 & 0,952 & 0,982 & 0,849 & 837,639 & 2974,928 & 1,562 & 35,239 \\
\hline
\end{tabular}

$* \mathrm{n}$ is The diffusion exponent

$*^{t_{50}}$ is time required for $50 \%$ of the drug to be released

$* * t_{90}$ is time required for $90 \%$ of the drug to be released

${ }^{*} \mathrm{RE}_{0-360 \mathrm{~h}}$ is the release efficiency of the drug from 0 to 360 hours

${ }^{\dagger} \mathrm{R}^{2}$-value is the value for regression co-efficient 
Table 3: Average inhibition zones diameters ( $\mathrm{mm})$ measured for the synthesized non-porous membranes.

\begin{tabular}{ccccc}
\hline Sample & \multicolumn{2}{c}{ Gram +ve bacteria } & Gram -ve bacteria & Fungi \\
\cline { 2 - 5 } & $\begin{array}{c}\text { Bacillus } \\
\text { subtilis }\end{array}$ & $\begin{array}{c}\text { Staphylococcus } \\
\text { aureus }\end{array}$ & Escherichia coli & $\begin{array}{c}\text { Candida } \\
\text { albicans }\end{array}$ \\
N1 & -ve & $-v e$ & -ve & -ve \\
N2 & $-v e$ & $-v e$ & $-v e$ & -ve \\
N3 & $-v e$ & $-v e$ & $-v e$ & -ve \\
N4 & $-v e$ & $-v e$ & $-v e$ & -ve \\
N1_CFX & 25 & 25 & 24 & $\mathbf{2 4}$ \\
N2_CFX & 24 & 24 & 23 & $\mathbf{2 3}$ \\
N3_CFX & 25 & 26 & 24 & $\mathbf{2 5}$ \\
\hline N4_CFX & $\mathbf{2 4}$ & $\mathbf{2 5}$ & $\mathbf{2 3}$ & $\mathbf{2 4}$ \\
\hline
\end{tabular}

Highly active $(+++)=($ inhibition zone $>20 \mathrm{~mm})$

Moderately active $(++)=($ inhibition zone $15-19 \mathrm{~mm})$

Slightly active $(+)=($ inhibition zone $10-14 \mathrm{~mm})$

Inactive $(-\mathrm{ve})=($ inhibition zone $<10 \mathrm{~mm})$ 


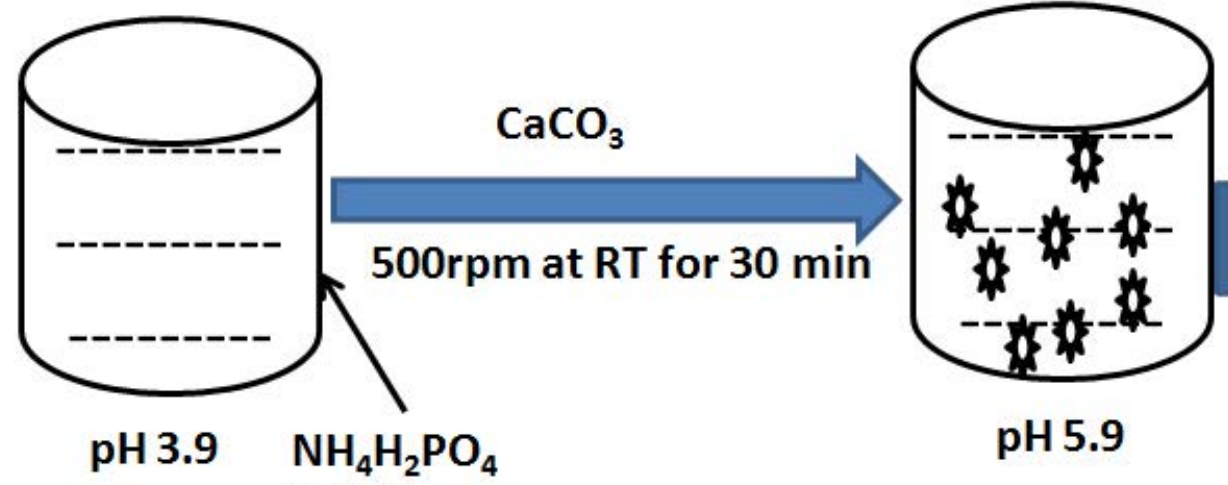

Solution

Filtration, washing and drying

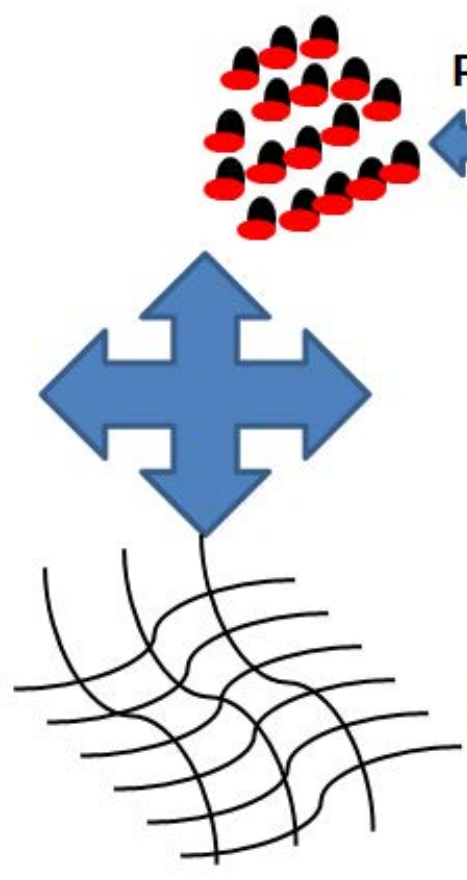

Gel polymer matrix
Physical mixing with $\mathrm{Nb}_{2} \mathrm{O}_{5}$

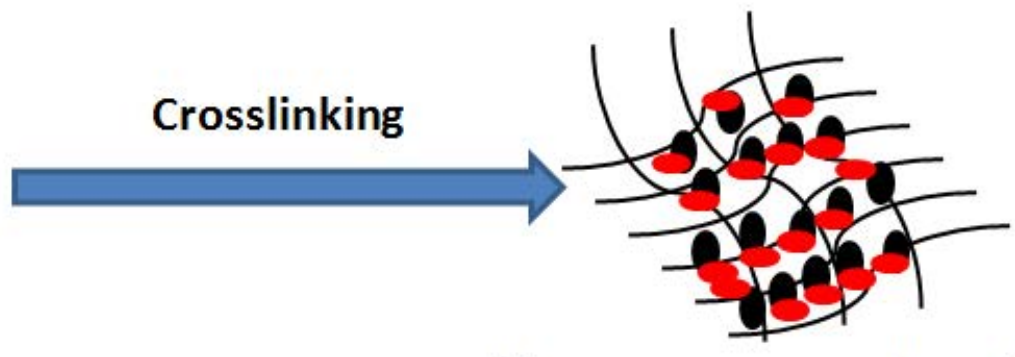

Homogenous membrane loaded with Nano-brushite and $\mathrm{Nb}_{2} \mathrm{O}_{5}$ 

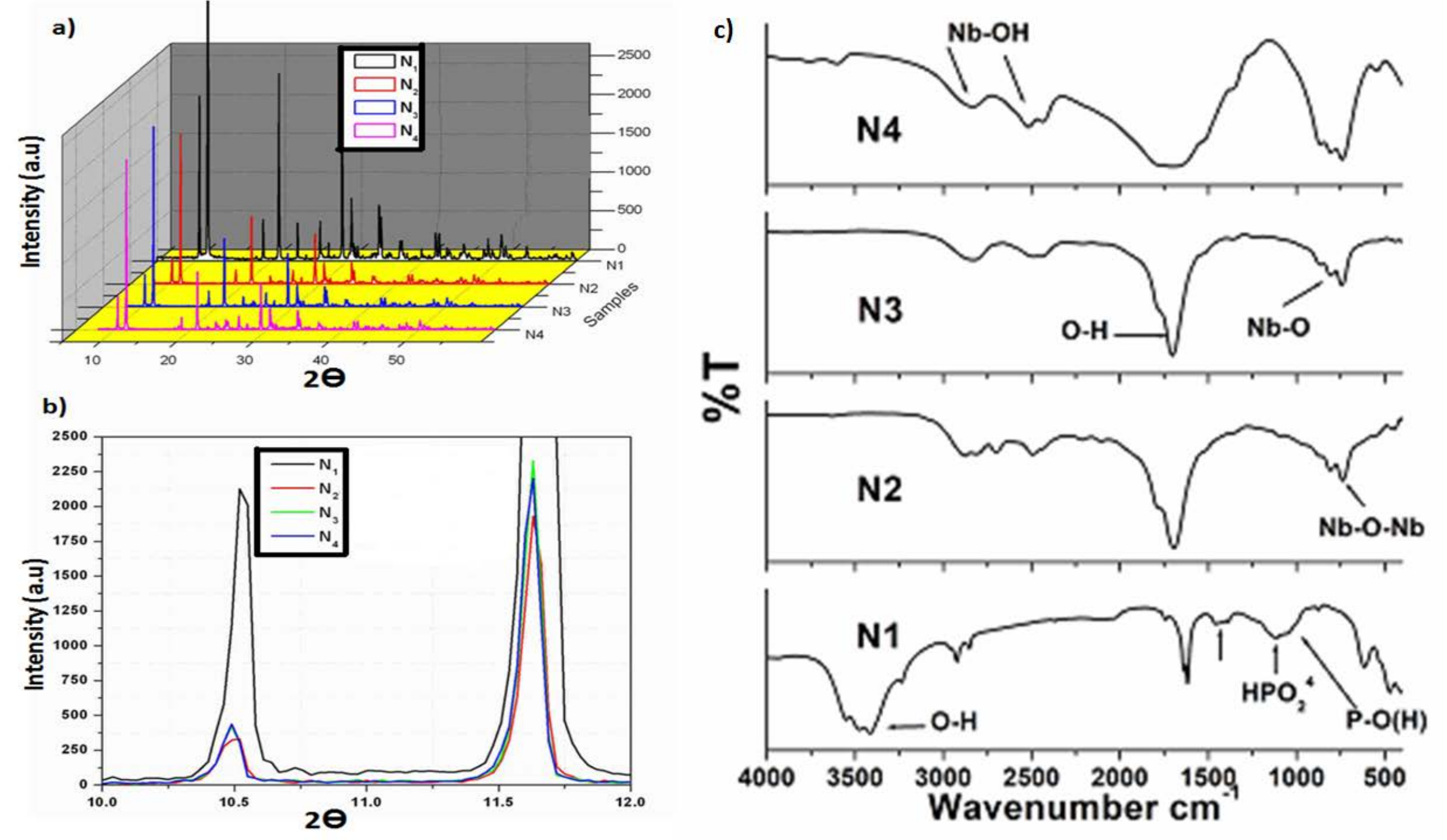


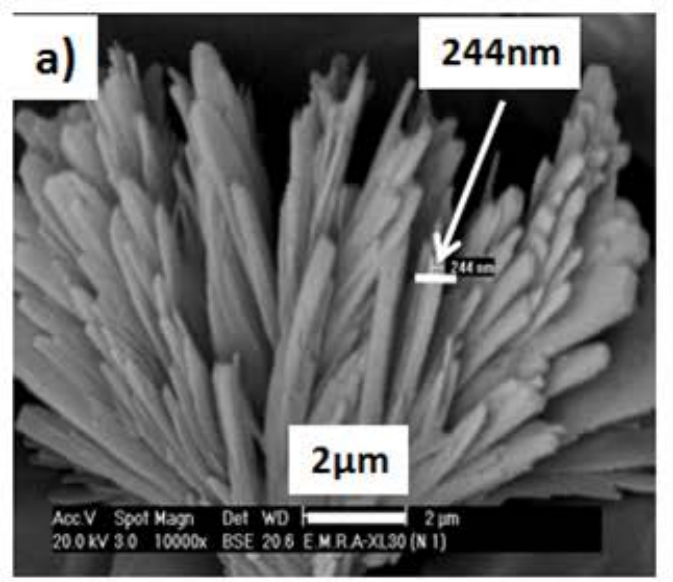

e)

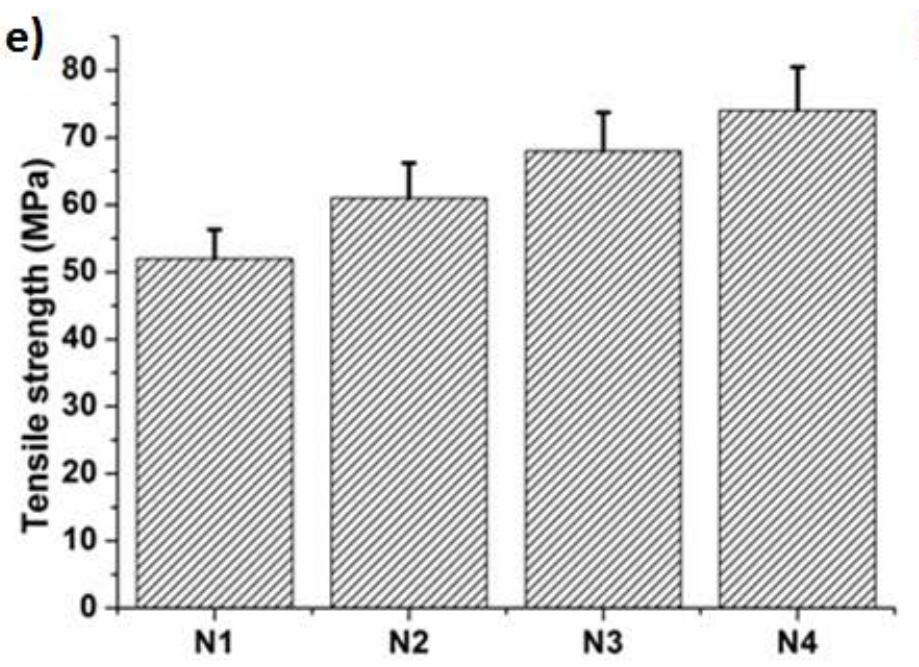

c)

d)
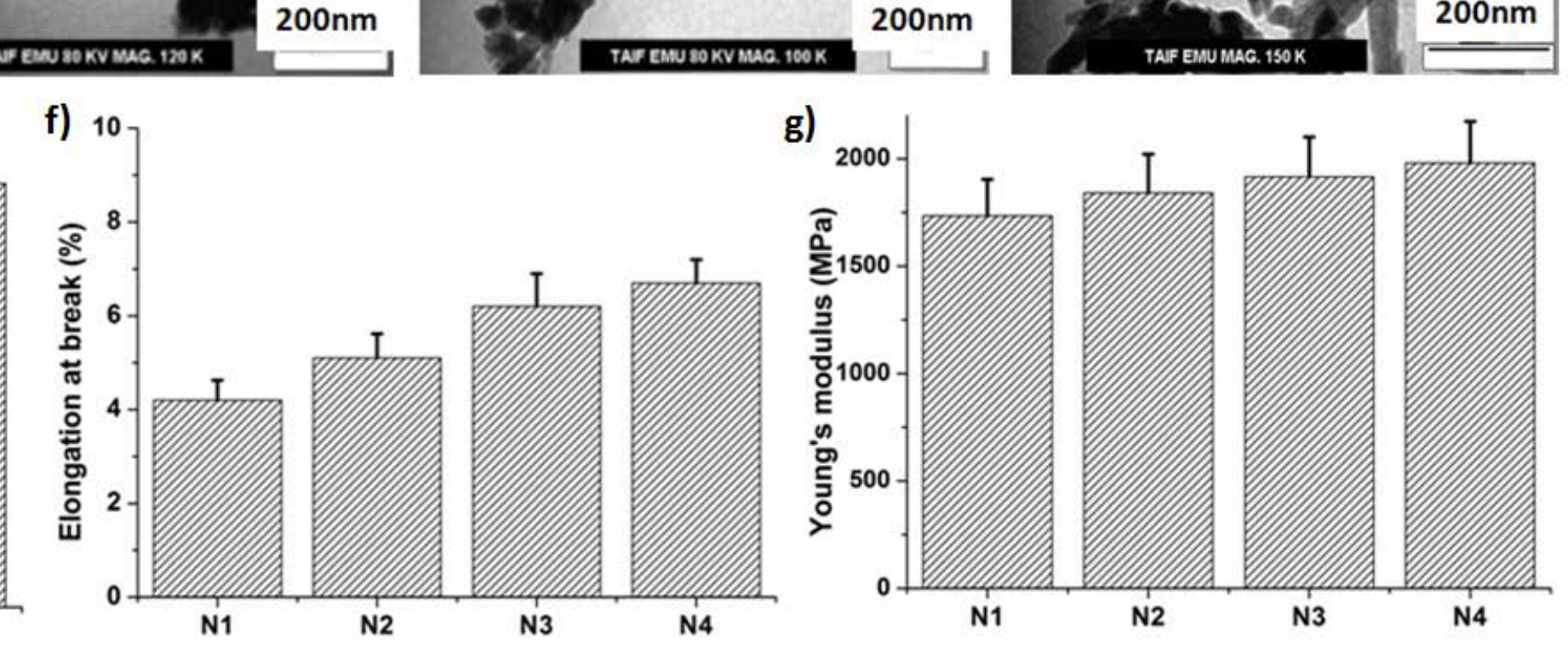

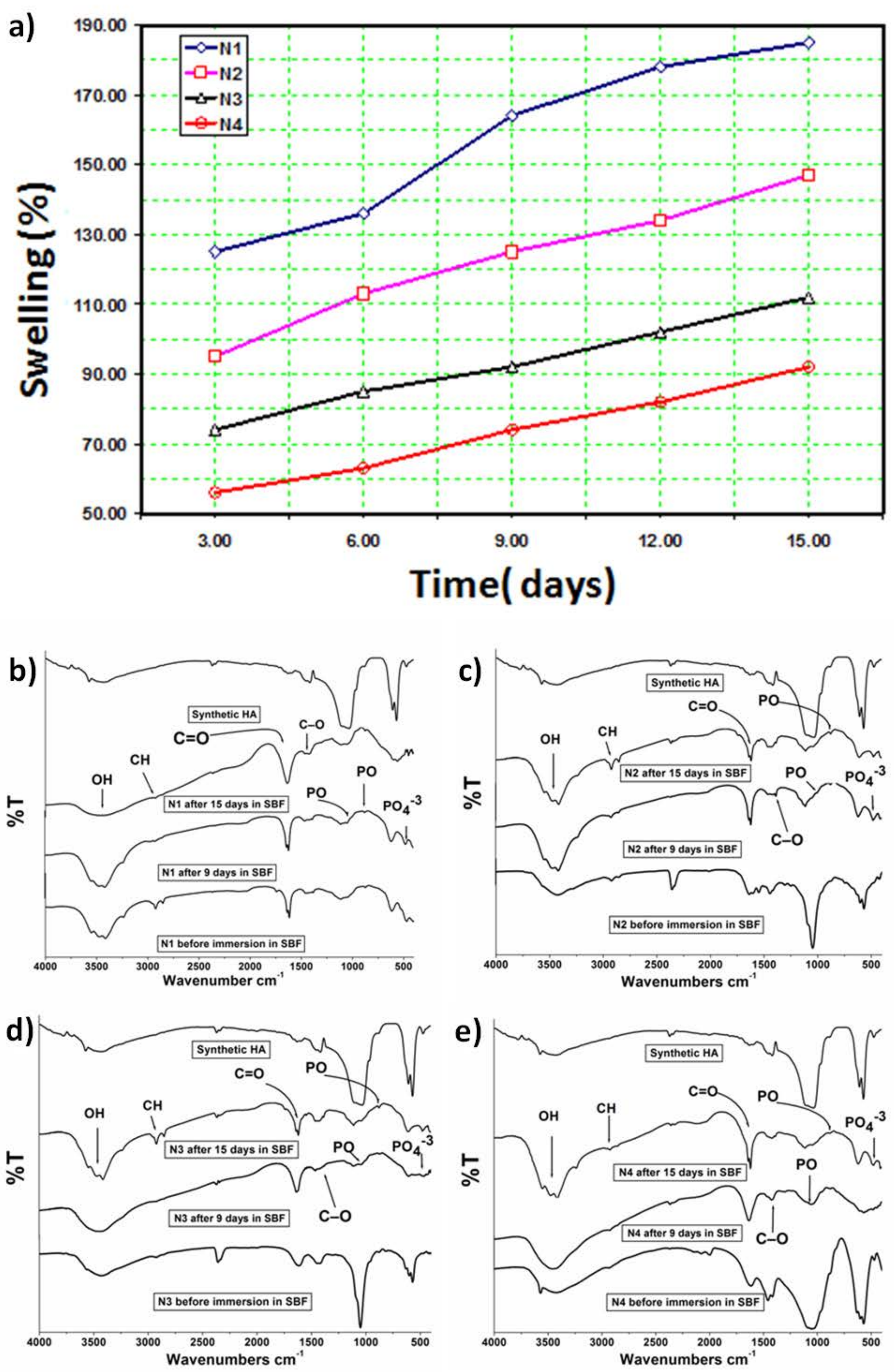


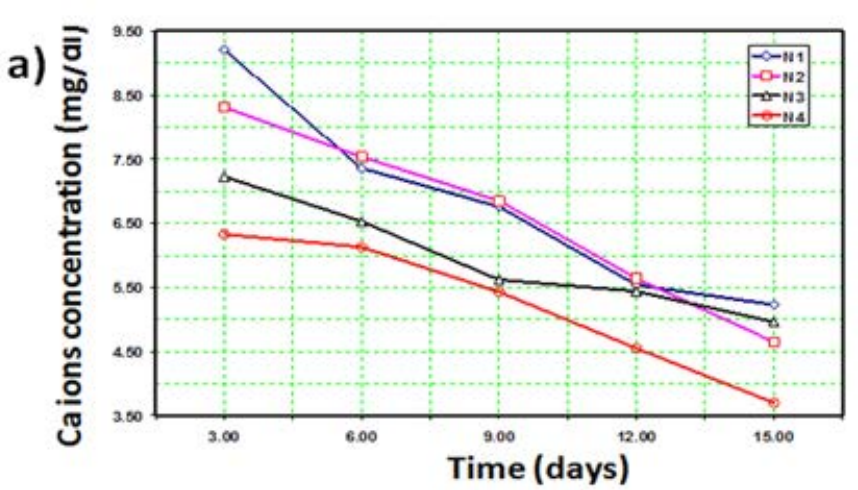

b)

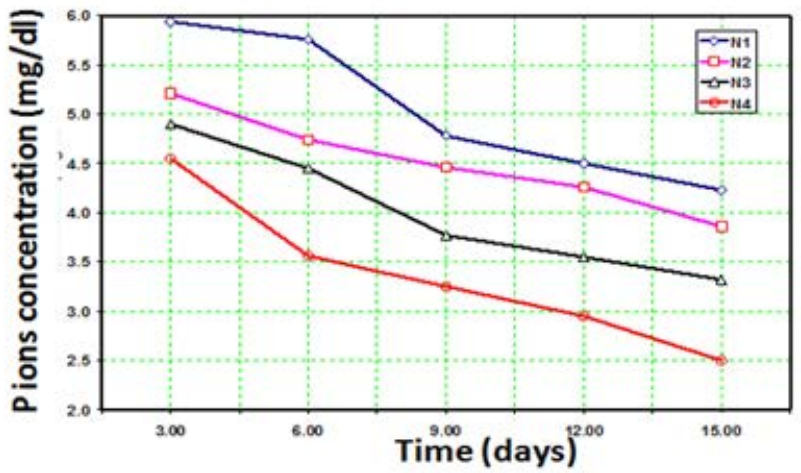

c)

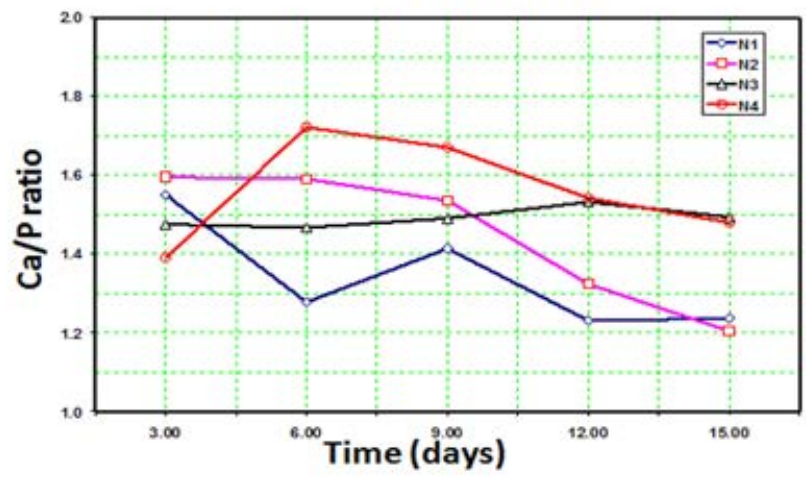

$\approx 60] d$
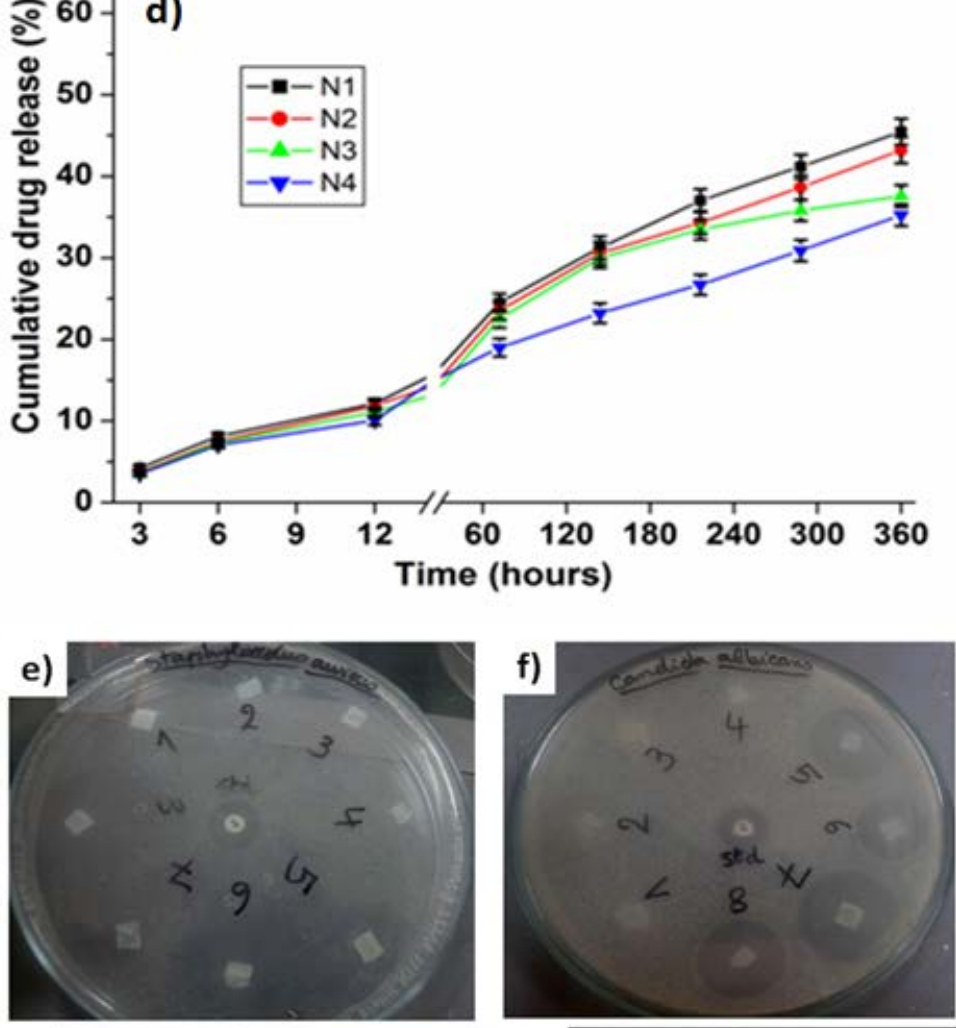

g)
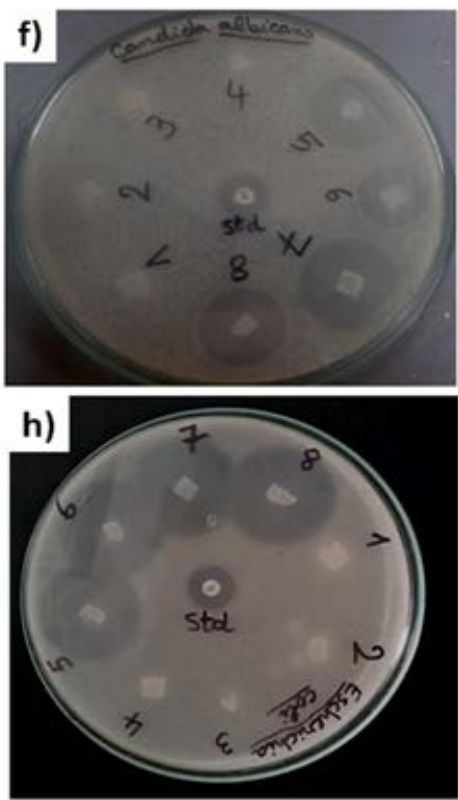